\title{
The Relationship between Business Knowledge and English Knowledge in Business English Teaching
}

\author{
Lu Sun ${ }^{1, a *}$ \\ ${ }^{1}$ Harbin University of Commerce, Harbin, China, 150028 \\ aSUN_LU1980@163.com
}

Keywords: Business English teaching; Business knowledge; Business culture

\begin{abstract}
This paper analyzes the relationship between English knowledge and business knowledge in business English teaching, and discusses the view that English knowledge is higher than business knowledge in Dichotomy. According to the basic purpose of business English and the general lack of work experience of Chinese college students The actual situation, put forward in the actual teaching should adhere to the "hands grasp, both hands should be hard" teaching methods.
\end{abstract}

\section{Introduction}

At present, China's business English teaching in accordance with the "English + business" model. This single teaching model allows students to mistakenly speak English, know business knowledge will be able to carry out business activities, resulting in the lack of business culture, language and culture out of touch, and ultimately lead to business activities failure. In fact, many outstanding students after graduation in the work of the exchange of difficulties. Although their language knowledge is very well grasped, the vocabulary is also very large, the basic skills of language is not bad, but in the actual business communication, because of the lack of business culture knowledge, with the native language of language communication standards, Conflict, and even make a joke, and sometimes even directly affect the success of business negotiations. Facts show that language and culture are inseparable and interdependent. Language is both a carrier of culture and an important medium of culture. Business English as a specialized use of English, contains a wealth of business culture. Therefore, business English teaching must include business culture teaching; cultural knowledge teaching and language knowledge and skills teaching should be carried out at the same time. Only then can we learn both authentic business English and develop a healthy business culture.

\section{Business English in Business}

Culture is deeply rooted in language, language contains rich cultural factors. Different nationalities, different countries of the traditional business customs, business etiquette and other differences. In English and Chinese language culture, some business English words and Chinese on the surface of the same, but the meaning is different. This is the language and cultural differences.

Different nationalities have different orientations for different values. In business contacts, different countries have different custom traditions and different ritual habits. For example, when the two sides meet, the Chinese staff will habitually respect the smoke to express the courtesy of enthusiasm (Would you please have a smoke? This practice in foreign countries, especially Europe and the United States is unpopular, because many people opposed to smoking or even smoking. There are also differences in the negotiating style of businessmen. If the Americans like straight to the point, so soon talked about the substantive stage, and hate the long circuitous conversation. Compared with them, the British calm, pay attention to the instrument, giving the feeling of lukewarm, and often quite shelves, and their former "British Empire" sense of superiority. Such as the cultural phenomenon in business English abound.

English and Chinese business vocabulary system has a large number of cultural vocabulary. Some words in English have cultural meaning, and Chinese counterparts have no cultural meaning. For example, men's well-known brand 'Golden Lion' has just begun translated as "Golden Lion", 
which in English culture, especially the United Kingdom has a rich positive connotation, reminiscent of "brave, majestic". The British use the lion as a national symbol, such as British Lion. But because the lion in our country is not familiar with the animals, should not let people associate, so "Golden Lion" in the Chinese market is not welcome, and later it was translated as "Goldlion", a "Lee" word reflects the pursuit of wealth The good wishes, so soon by the majority of our consumers of all ages.

\section{Discussion on "Dichotomy" in Business English Teaching}

Dichotomy is a logical term that refers to a method of distinguishing two contradictory concepts by whether an object has a certain attribute. This word is used to explain business English, the business knowledge and knowledge of English is divided into two points. There is a view that with the deepening of reform and opening up, more and more people are eager to improve the level of English, and aware of the importance of using English for trade activities. This view is based on the original intention of learning English knowledge, emphasizing the importance of English knowledge in the actual teaching process, that is, business English teaching English knowledge is higher than business knowledge.

I believe that business knowledge is a complex knowledge of the subject, from the micro-point of view of the trade process, it includes inquiry, quotes, quotation of the offer, the firm, the signing of the contract, the opening of the letter of credit, payment, transportation, insurance, Complaints and claims; from a macro point of view, but also includes the internal management of trade entities and external arrangements for the handling of external arrangements. Each of these links in the success of the transaction plays an important role, can not be ignored. Moreover, from the business English to complete the task point of view, its purpose is to communicate through language to deal with specific business matters. So just pay attention to the language point of view, it will be in the actual trade, business problems encountered in the face. According to the characteristics of this comprehensive course, we can easily find that business English business knowledge and English play the same important role, only in the teaching process to successfully deal with the relationship between the two, adhere to the " "In order to play in the actual use of business English role.

\section{Business and English Knowledge Have the Same Important Role}

"Dichotomy" is an effective way to analyze the relationship between business and English in business English. However, the effective way must be theory with practice, college students in business English learning has a special reality. China's college students generally come from the high school graduates, they rely on the economy in the parents, not engaged in independent economic activities, are pure consumer groups, even the mother tongue system of basic business theory is also vague. In this case, students in the process of learning business English, not only faced with the difficulties of English language, but also faced with the challenges of business expertise. Because of their lack of experience, they often encounter stumbling on the understanding and use of business knowledge, which may even affect their interest in learning business English and confidence. For example, in the seventh chapter of Cambridge Business English published by Huaxia Publishing House, the student first met the term "an irrevocable letter of credit". Although students can understand the meaning of each word in the phrase by looking up the dictionary, it is not so easy to understand the meaning of the letter of credit, and whether it is a textbook, a workbook, or a self-study manual. There is no detailed explanation of this term. In order to make a clear understanding of the meaning and purpose of the term, the teacher must spend a lot of time in the brief classroom, including the definition of the letter of credit, the participant involved, the process of the letter of credit, the role and characteristics of the letter of credit content. If the teacher simply emphasizes the importance of the English language, how to listen to the students, read and write letters of credit these words, or the letter of credit as a reading material, it is far from the purpose of business English teaching. For students, they simply cannot use this important payment method correctly in future work. 
Business English, as the name suggests, refers to the use of English in the business environment, between customers and customers to trade the name of the goods, quantity, quality, discount, the packaging of goods, transportation and insurance to take the trouble of negotiations and consultations until the two sides satisfied Stop by. In this process, the language is only a carrier of information transmission, and the central content is the transaction of every detail. Such negotiations and consultations require that the person involved must be able to understand and use the business knowledge, thereby increasing the trade profits. Imagine a person who can use the daily English conversation but lack business knowledge in this kind of conversation can play a big role? Even if they can understand each other's requirements, how to safeguard their own interests? The language of the strengths can not make up for professional knowledge Lack of lack of. Therefore, in business English teaching must be equal attention to business knowledge. Also in Huaxia Publishing House, "Cambridge Business English", for example, the book of each unit almost all involved in professional business knowledge, really see the importance of business knowledge in business English. Some Suggestions on Strengthening Business Knowledge Learning in Business English Learning

\section{To Establish a Scientific Business English Learning Support System}

Business English learning support system refers to the preparation of business English in advance to learn the relevant content of the system. This system consists of three components: business English, business knowledge and basic English knowledge. They form a very solid knowledge of the triangle, so that students firmly grasp the knowledge of business English. Before studying Business English, students can study this part of the relevant professional business knowledge and other countries' cultural practices through their mother tongue, such as "International Trade Practice", "Business and Speaking" and "Anglo-American Culture". Solid foundation. This way, you can provide students with more theoretical and intellectual background, increase students 'interest in learning this course, and improve students' confidence in learning business English. If the students directly to learn business English knowledge, and then explain the business knowledge in the later period, it will reduce the results of teaching and learning, and even crack down on students to learn business English enthusiasm.

If you do not have enough time to learn business knowledge such as economics and finance in advance, you can also add professional business knowledge at the beginning of each chapter or every section by the Business English Teacher System. In this supplementary teaching, the instructor should take full account of the actual situation of the students to teach, if necessary, can be used in the mother tongue of the business books as a student reading material. Is still published by Huaxia Publishing House "Cambridge Business English" Section VII of the letter of credit, for example, the contents of the textbook for the real use of letters of credit is clearly inadequate, teachers can choose some of the international trade practice materials to add, of course, Which also requires adequate teaching time when arranging syllabuses.

\section{Conclusions}

According to the above analysis we can see that business English business knowledge and English knowledge has the same important significance, both in the actual trade process plays a role can not be ignored. Therefore, the teaching of business English should also adhere to the "hands grasp, both hands should be hard" approach, dealing with business knowledge and the relationship between English knowledge.

\section{Acknowledgements}

This paper is supported by Philosophy and Social Scientific Research Project Foundation of Heilongjiang Province (No.14C009). 


\section{References}

[1]. Wei Chuanli, Practice and theoretical basis of public management research in China, China Electronic Commerce .2012. (10)

[2]. Wei Chuanli, On the Problems in the Study of Public Administration in China, China's Foreign Trade $2012(8)$

[3]. Sun Lu, Study on Self-learning of Business English Students by Network, MEICI2015, 2015.10

[4]. Sun Lu, the Practice of Business English Cooperative Learning in the Network Environment, ICEMC2016, 2016.05

[5]. Sun Lu, raining of Foreign Trade-Oriented Business English Major, ICEMC2016, 2016. 05

[6]. Sun Lu, On Using Podcasting to Teach in Mobile Foreign Language Learning, EMCM2016, 2016.12

[7]. Sun Lu, Discussion on the Reform of Foreign Language Teaching in College, EMCM2016, 2016.12

[8]. Sun Lu, Discussion on the Training Mode of Business English Major, EMCS2017.05

[9]. Sun Lu, Study on Business English Teaching, EMCS2017.05

[10]. Wei Chuanli, SME technical efficiency and scale revenue calculation methods and selection of indicators, Computer modeling and new technologies, 2014.12 